\title{
Diagnosing a red eye: an allergy or an infection?
}

\author{
L Lambert \\ *Corresponding author, lynn@amayeza-info.co.za
}

\begin{abstract}
A red eye is the cardinal sign of ocular inflammation, and is one of the most common ophthalmological complaints. Inflammation of almost any part of the eye, including the lacrimal glands and eyelids, or a faulty tear film, can lead to a red eye. The condition is usually benign, self-limiting and can be managed effectively in general practice. While there may be numerous causes of a red eye, conjunctivitis is the most common. A thorough patient history and physical examination of the eye are essential in the management of a red eye when differentiating between an allergic and an infectious cause.
\end{abstract}

Keywords: red eye, allergy, infection, inflammation, conjunctivitis, viral, bacterial

\section{Introduction}

A red eye is caused by the dilation of blood vessels in the eye, and is one of the most common ocular complaints experienced by patients. ${ }^{1,2}$ The diagnosis of a red eye may be aided by the differentiation between ciliary and conjunctival injection or redness:

- Ciliary injection involves branches of the anterior ciliary arteries, and indicates inflammation of the cornea, iris or ciliary body

- Conjunctival injection mainly affects the posterior conjunctival blood vessels. Since these vessels are more superficial than the ciliary arteries, they produce more pronounced redness.

Numerous conditions may be associated with a red eye, including conjunctivitis, blepharitis, corneal injury, episcleritis, iritis, keratitis, and a bacterial or viral infection. ${ }^{1}$ While the diagnosis of a red eye can vary from relatively innocuous and trivial conditions to those that are more devastating, conjunctivitis is the most common cause of a red eye. ${ }^{2}$ The focus of this article is to differentiate between an infectious or an allergic cause of a red eye.

\section{Patient evaluation}

Limited epidemiological data are available on red eyes, nor is there evidence-based guidance as to the management thereof. However, a history and overall patient assessment are useful and confirmatory in the decision to manage or refer. ${ }^{3} \mathrm{~A}$ thorough patient history and eye examination may provide clues to the aetiology of a red eye.

The history should include questions about: ${ }^{2}$
- Unilateral or bilateral eye involvement

- The duration of symptoms

- The type and amount of discharge

- Visual changes

- The severity of the pain

- Photophobia

- The presence of allergies or systemic disease.

The eye examination should include the eyelids, lacrimal sac, pupil size and reaction to light, corneal involvement, and the pattern and location of hyperaemia. Preauricular lymph node involvement and visual acuity should also be assessed. ${ }^{2}$

Ophthalmologist referral is necessary when there is: ${ }^{3}$

- Impaired vision

- The presence of a foreign body sensation: This is the cardinal symptom of an active corneal process. Objective evidence of a foreign body sensation, in which the patient is unable to spontaneously open the eye or keep it open, suggests corneal involvement, and such patients warrant emergent or urgent referral. By comparison, many patients report a "scratchy feeling," "grittiness" or a sensation "like sand in my eyes" with an allergy, viral conjunctivitis or dry eyes. This is a subjective foreign body sensation and does not necessarily suggest an active corneal process requiring referral.

- Photophobia: This may be present in patients with an active corneal process. These patients may also have objective signs of foreign body sensation and require referral. 


\section{Conjunctivitis: the most common cause of a red eye}

Conjunctivitis is the most common cause of a red eye, and is characterised by inflammation of the superficial conjunctival blood vessels that cover the ocular surface, as well as cellular infiltration and exudation. It must be differentiated on the basis of aetiology, which can either be infectious, e.g. viral, bacterial or chlamydial; or non-infectious, e.g. allergic., ${ }^{1,4}$

\section{Viral conjunctivitis}

Viral conjunctivitis is characterised by an acute follicular conjunctival reaction, as well as preauricular or submandibular lymphadenopathy. ${ }^{4}$ Viral conjunctivitis usually spreads through direct hand-to-eye contact, medical instruments, swimming pool water or personal items. It is often associated with an upper respiratory infection spread through coughing. In most cases, the clinical presentation of viral conjunctivitis is mild, with spontaneous remission after 1-2 weeks. Treatment is supportive, and may include cold compresses, ocular decongestants and artificial tears. Topical antibiotics are rarely necessary because secondary bacterial infections are uncommon. ${ }^{2}$

To prevent the spread of viral conjunctivitis, patients should be counselled to practise strict hand washing and avoid sharing personal items which may spread infection. Referral to an ophthalmologist is necessary if the symptoms do not resolve after 7-10 days, or if there is corneal involvement. Furthermore, suspected ocular herpetic infection also warrants immediate referral. $^{2}$

The most common causative viruses include adenovirus, herpes simplex and molluscum contagiosum. ${ }^{4}$ Viral conjunctivitis caused by the adenovirus is highly contagious, whereas conjunctivitis caused by the other viruses is less likely to spread. ${ }^{2}$

\section{Adenovirus conjunctivitis}

Adenovirus conjunctivitis may present as a mild infection and progress to a more severe syndrome, such as pharyngoconjunctival fever or epidemic keratoconjunctivitis. Pharyngoconjunctival fever predominantly affects children, and is often accompanied by an upper respiratory tract infection. Epidemic keratoconjunctivitis, commonly known as "pink eye", is typically not associated with systemic manifestations. These infections are often bilateral and associated with preauricular lymphadenopathy. The incubation period is from 7-9 days before the onset of symptoms, such as ocular itching, tearing, redness and photophobia. In severe cases, subconjunctival bleeding may occur, and the cornea may become affected in the second week. Treatment is usually supportive. Cold compresses and lubricating eyedrops may be used to relieve discomfort. Topical antihistamine eyedrops may be applied to alleviate severe itching. ${ }^{4}$

\section{Herpes simplex conjunctivitis}

Infants and young children are predominantly affected by primary ocular herpes simplex virus (HSV) infection. It presents as a follicular conjunctivitis that manifests as a red, teary eye associated with a typical vesicular eruption on the eyelids. The treatment may include the topical administration of aciclovir ointment for the skin lesions. ${ }^{4}$

\section{Molluscum contagiosum keratoconjunctivitis}

Molluscum contagiosum can cause follicular conjunctivitis, in association with an eyelid lesion. In most cases, the lesion is a small, pearly umbilicated nodule on or near the lid margin. Multiple lesions may be present, especially in a patient with human immunodeficiency virus infection. Treatment involves incision and curettage of the symptomatic lesions. The asymptomatic lesions are usually self-limiting if left for long enough. ${ }^{4}$

\section{Bacterial conjunctivitis}

Bacterial conjunctivitis is highly contagious, and is most commonly spread through contaminated hand-to-eye contact. ${ }^{2}$ Based on the duration and severity of signs and symptoms, bacterial conjunctivitis is categorised as hyperacute, acute or chronic.

\section{Hyperacute bacterial conjunctivitis}

Hyperacute bacterial conjunctivitis is often associated with Neisseria gonorrhoeae in sexually active adults, while neonates can acquire it at birth. The infection has a sudden onset, and rapidly progresses to corneal perforation. Hyperacute bacterial conjunctivitis is characterised by copious, purulent discharge that reforms quickly after it is wiped away, pain, diminished vision and preauricular lymphadenopathy. ${ }^{2,5}$ Treatment includes irrigation of the eye with a saline solution, a single immediate intramuscular injection with ceftriaxone, followed by topical ciprofloxacin. ${ }^{5}$ Patients need prompt ophthalmological referral for aggressive management since these bacteria can cause penetration of the intact cornea and lead to abscess formation. ${ }^{2,5}$

\section{Acute bacterial conjunctivitis}

Acute bacterial conjunctivitis is the most common form of bacterial conjunctivitis. Acute bacterial conjunctivitis in adults is often caused by a Staphylococcus aureus infection, whereas Streptococcus pneumoniae and Haemophilus influenzae infections are more common pathogens in children. ${ }^{2}$ The organisms causing acute bacterial conjunctivitis may be spread by hand to eye contact or by colonisation of the adjacent mucosal tissues, such as the nasal or sinus mucosa. Acute bacterial conjunctivitis initially presents unilaterally. However, the second eye is often affected soon thereafter. A sticky discharge that causes the eyelids to adhere to each other in the morning, as well as a foreign body sensation, are typical symptoms. ${ }^{4}$ As a result, patients often complain of crusting of the eyelids, which results from the mucopurulent discharge that causes matting of the eyelashes. ${ }^{5}$ Acute bacterial conjunctivitis does not affect vision or pupillary reactions. In addition, the cornea and anterior chamber should be clear. However, on examination, generalised redness of the conjunctiva is present. ${ }^{4}$ 


\section{Chronic bacterial conjunctivitis}

Chronic bacterial conjunctivitis is characterised by signs and symptoms that persist for at least four weeks, with frequent relapses. Patients with chronic bacterial conjunctivitis should be referred to an ophthalmologist. ${ }^{2}$ In general, bacterial conjunctivitis is benign and self-limiting and highly responsive to treatment.

Chloramphenicol ointment or drops are effective owing to their broad-spectrum activity. In addition to topical antibiotic treatment, patients should be made aware of the importance of proper hygiene and hand washing. Patients should be referred in cases when the conjunctivitis is recurrent or refractory to initial treatment. ${ }^{4}$

\section{Chlamydial conjunctivitis}

Chlamydia is a common cause of chronic follicular conjunctivitis. ${ }^{2,4}$ Chlamydial conjunctivitis should be suspected in sexually active patients who have typical signs and symptoms, but do not respond to standard antibiotic treatment, such as chloramphenicol. ${ }^{2}$ Treatment includes oral doxycycline to clear the genital infection. The patient's sexual partner should also be treated. ${ }^{2,6}$

\section{Allergic conjunctivitis}

Allergic conjunctivitis is often associated with allergic rhinitis, eczema or asthma. ${ }^{2}$ Acute allergic rhinoconjunctivitis (hay fever) is the most common form of ocular and nasal allergy. ${ }^{4}$ Transient attacks of itchiness, tears and redness are common symptoms, with itching of the eyes being the most apparent feature. ${ }^{2,4}$ Associated features, such as sneezing and nasal discharge, may be present. Oedema of the eyelid and chemosis may be present in severe cases. Treatment using antihistamine drops provides symptomatic relief. ${ }^{4}$

Table I: Differential diagnosis of a red eye due to conjunctivitis ${ }^{2}$

\begin{tabular}{|c|c|c|c|}
\hline Condition & Signs & Symptoms & Cause \\
\hline Viral conjunctivitis & $\begin{array}{l}\text { - Normal vision } \\
\text { - } \text { to light } \\
\text { - Diffuse conjunctival redness } \\
\text { - Preauricular lymphadenopathy } \\
\text { - Lymphoid follicle on the under } \\
\text { surface of the eyelid }\end{array}$ & $\begin{array}{l}\text { - Mild to no pain } \\
\text { - Diffuse hyperaemia } \\
\text { - Occasional gritty discomfort, } \\
\text { with mild itching } \\
\text { - Watery to serous discharge } \\
\text { - Photophobia (uncommon) } \\
\text { - Often unilateral at onset, with } \\
\text { the second eye involved } \\
\text { - within 1-2 days } \\
\text { - Severe cases may cause } \\
\text { subepithelial corneal opacities } \\
\text { and pseudomembranes }\end{array}$ & $\begin{array}{l}\text { - Adenovirus (most common) } \\
\text { - Enterovirus } \\
\text { - Varicella-zoster virus } \\
\text { - Epstein Barr virus } \\
\text { - Herpes simplex virus } \\
\text { - Influenza viruses }\end{array}$ \\
\hline $\begin{array}{l}\text { Bacterial conjunctivitis (acute and } \\
\text { chronic) }\end{array}$ & $\begin{array}{l}\text { - Eyelid oedema } \\
\text { - Preserved visual acuity } \\
\text { - Conjunctival redness } \\
\text { - Normal pupil reaction } \\
\text { - No corneal involvement }\end{array}$ & $\begin{array}{l}\text { - Mild to moderate pain, with a } \\
\text { stinging sensation } \\
\text { - A red eye with a foreign body } \\
\text { sensation } \\
\text { - Mild to moderate purulent } \\
\text { discharge } \\
\text { - Mucopurulent secretions with } \\
\text { bilateral glued eyes upon } \\
\text { awakening (best predictor) }\end{array}$ & $\begin{array}{l}\text { Common pathogens in children: } \\
\text { - Streptococcus pneumoniae } \\
\text { - Non-typeable Haemophilus } \\
\text { - influenzae } \\
\text { Common pathogen in adults: } \\
\text { - Staphylococcus aureus } \\
\text { Other pathogens: } \\
\text { - Staphylococcus spp. } \\
\text { - Moraxella spp. } \\
\text { - Neisseria gonorrhoeae } \\
\text { - Gram-negative organisms, e.g. } \\
\text { Escherichia coli } \\
\text { - Pseudomonas spp. }\end{array}$ \\
\hline $\begin{array}{l}\text { Bacterial conjunctivitis } \\
\text { (hyperacute) }\end{array}$ & $\begin{array}{l}\text { Chemosis, with possible corneal } \\
\text { involvement }\end{array}$ & $\begin{array}{l}\text { - Severe pain } \\
\text { - Copious, purulent discharge } \\
\text { - Diminished vision }\end{array}$ & Neisseria gonorrhoeae \\
\hline Allergic & $\begin{array}{l}\text { - Visual acuity preserved } \\
\text { - Pupils reactive to light } \\
\text { - Conjunctival redness } \\
\text { - No corneal involvement } \\
\text { - Large cobblestone papillae } \\
\text { under the upper eyelid } \\
\text { - Chemosis }\end{array}$ & $\begin{array}{l}\text { - Bilateral eye involvement } \\
\text { - Painless tearing } \\
\text { - Intense itching } \\
\text { - Diffuse redness } \\
\text { - A stringy or ropy watery } \\
\text { - discharge }\end{array}$ & $\begin{array}{l}\text { - Airborne pollen } \\
\text { - Dust mites } \\
\text { - Animal dander } \\
\text { - Feathers } \\
\text { - Other environmental antigens }\end{array}$ \\
\hline
\end{tabular}




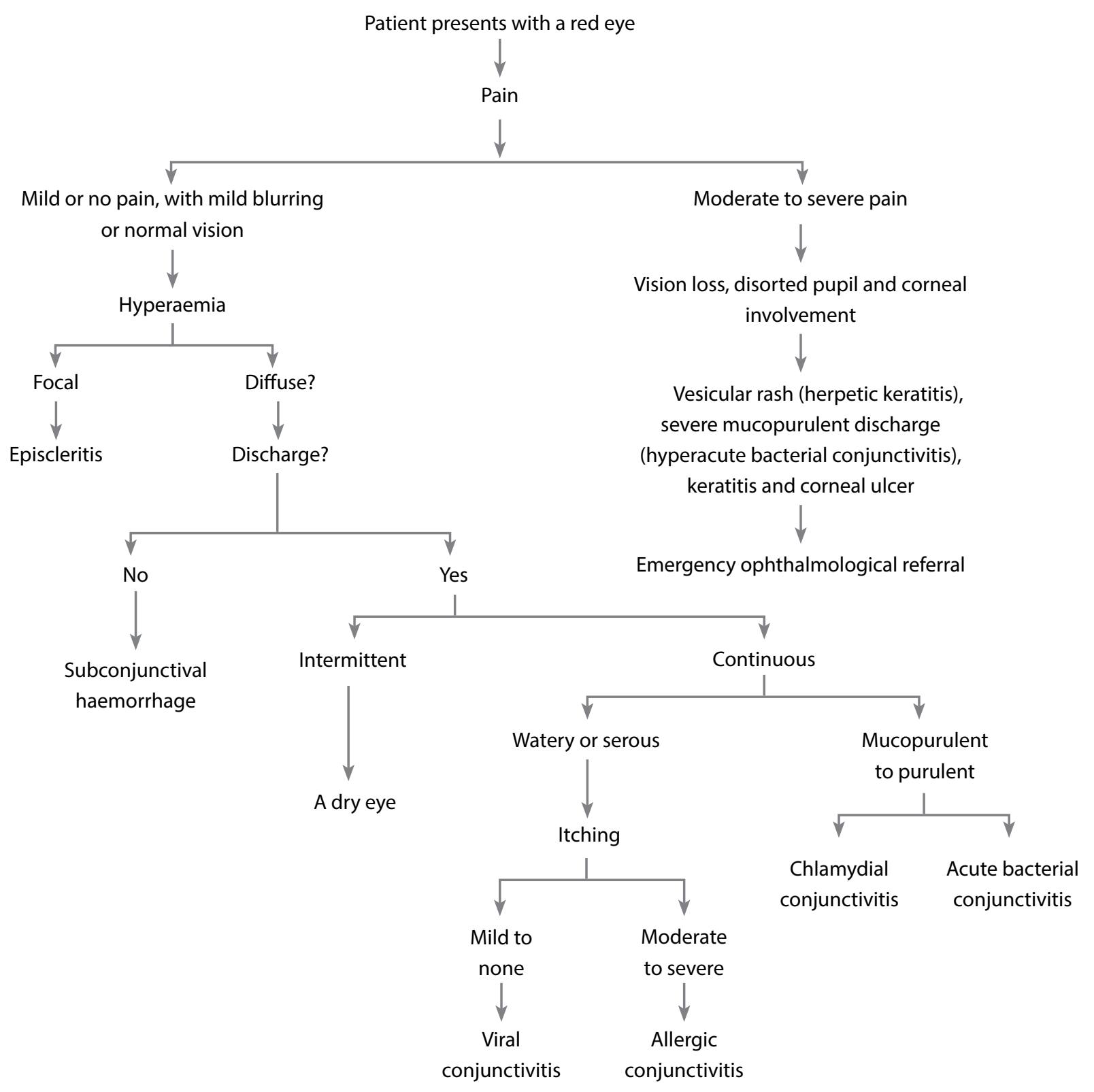

Figure 1: Algorithm to use when diagnosing the cause of a red eye ${ }^{2}$

\section{Vernal keratoconjunctivitis}

Vernal keratoconjunctivitis is a bilateral, recurrent disorder that is common in the drier parts of South Africa. Children and teenagers are mostly affected and the condition worsens seasonally. There is often associated atopy, with a history of asthma and eczema in infancy. Itching associated with tears, photophobia and the sensation of a foreign body in the eye are characteristic symptoms. Secondary skin changes to the eyelids occur as a consequence of persistent eye rubbing. ${ }^{4}$

The differential diagnosis for a red eye caused by conjunctivitis is summarised in Table I. An algorithm to differentiate between an allergic or infectious cause of red eye is shown in Figure $1 .^{2}$

\section{Other infectious or non-infectious causes of a red eye}

\section{Corneal abrasion}

Corneal abrasion is diagnosed based on the clinical presentation and eye examination. Fluorescein staining under a cobalt blue filter or Wood lamp is confirmatory. A branching pattern of staining suggests HSV infection or a healing abrasion. HSV infection with corneal involvement warrants ophthalmological referral within 1-2 days. It is good practice to check for a retained foreign body under the upper eyelid in patients with corneal abrasion. Treatment includes supportive care, cycloplegic medication and pain control. Referral to an ophthalmologist is indicated if the symptoms worsen or do not resolve within 48 hours. ${ }^{2}$

\section{Keratitis}

Keratitis may be infective or non-infective in origin. ${ }^{4}$

Infective keratitis is often unilateral and may be bacterial, viral or fungal. The symptoms of a red eye may be accompanied by pain, photophobia, decreased vision and discharge.

Bacterial keratitis is uncommon in a normal eye as the corneal epithelium provides a barrier against many organisms. Most central corneal ulcers follow a breach in this layer, secondary to 
Table II: Differentiatiion between an allergy or an infection based on the presenting symptoms ${ }^{7}$

\begin{tabular}{|c|c|c|c|c|}
\hline Presentation & Exclude & Diagnosis & Pathology & Treatment \\
\hline $\begin{array}{l}\text { - Three-day history of red } \\
\text { left eye } \\
\text { - Unchanged vision } \\
\text { - Mucopurulent discharge } \\
\text { causing eyelids to stick } \\
\text { together upon waking }\end{array}$ & $\begin{array}{l}\text { Viral: } \\
\text { - Unilateral } \\
\text { - Discharge not watery } \\
\text { - Lymph nodes absent } \\
\text { Allergic: } \\
\text { - Unilateral } \\
\text { - Discharge not mucoid } \\
\text { - Itchiness not a complaint }\end{array}$ & $\begin{array}{l}\text { Acute bacterial } \\
\text { conjunctivitis }\end{array}$ & $\begin{array}{l}\text { - Unilateral swollen eyelids } \\
\text { - Diffuse conjunctival } \\
\text { redness } \\
\text { - Absence of preauricular } \\
\text { lymph nodes }\end{array}$ & $\begin{array}{l}\text { Resolution expedited } \\
\text { by topical antibiotics } \\
\text { (chloramphenicol or } \\
\text { tobramycin) }\end{array}$ \\
\hline $\begin{array}{l}\text { - Recurrent attacks of } \\
\text { redness and itchiness of } \\
\text { both eyes } \\
\text { - Swelling of the eyelids } \\
\text { - Sneezing } \\
\text { - Mucoid discharge from } \\
\text { nose and eyes also } \\
\text { present }\end{array}$ & $\begin{array}{l}\text { Bacterial: } \\
\text { - Bilateral } \\
\text { - Discharge not } \\
\text { mucopurulent } \\
\text { Viral: } \\
\text { - Discharge not watery } \\
\text { - No follicular reaction } \\
\text { - Swollen lymph nodes } \\
\text { absent }\end{array}$ & Acute allergic conjunctivitis & $\begin{array}{l}\text { Bilateral conjunctivitis, with } \\
\text { transient swelling of the } \\
\text { eyelids and conjunctiva }\end{array}$ & $\begin{array}{l}\text { Cold compress, } \\
\text { Ophthalmic antihistamines, } \\
\text { mast cell stabilisers } \\
\text { or topical glucocorticoids }^{8}\end{array}$ \\
\hline $\begin{array}{l}\text { Redness and discomfort } \\
\text { in the left eye, which } \\
\text { spreads to the right eye } \\
\text { after two days } \\
\text { - Visual acuity unaffected } \\
\text { - Watery discharge from } \\
\text { both eyes } \\
\text { - Tender swelling in front } \\
\text { of both eyes }\end{array}$ & $\begin{array}{l}\text { Bacterial: } \\
\text { - Discharge not } \\
\text { mucopurulent } \\
\text { - Presence of swollen } \\
\text { lymph nodes } \\
\text { Allergic: } \\
\text { - Itching is not the main } \\
\text { complaint } \\
\text { - Conjunctiva not swollen }\end{array}$ & Bilateral viral conjunctivitis & $\begin{array}{l}\text { Bilateral follicular } \\
\text { reaction and preauricular } \\
\text { lymphadenopathy }\end{array}$ & $\begin{array}{l}\text { Supportive: } \\
\text { - Cold compress } \\
\text { - Artificial tears }\end{array}$ \\
\hline
\end{tabular}

either trauma or a pre-existing ocular surface disease. Other risk factors include a history of wearing contact lenses and systemic immunosuppression. Signs include an epithelial defect which stains with fluorescein, stromal infiltrates and pus in the anterior chamber. Discontinuation of wearing contact lenses and the use of a plastic eye shield may be initial interventions. Since bacterial keratitis has the potential to progress rapidly to corneal perforation, strict specialist referral is advised. ${ }^{4}$

Herpes simplex keratitis typically presents with signs that include decreased visual acuity, a watery discharge and epithelial lesions, called dendritic ulcers. Topical acyclovir, applied five times daily, is generally used. Topical steroids should be avoided in these patients as corneal perforation may ensue. ${ }^{4}$

Fungal keratitis is a significant cause of blindness, and presents as a red, painful eye associated with a decrease in visual acuity. Fungal ulcers are less aggressive than bacterial ulcers, and are slow spreading and dull grey in appearance, with feather-like extensions. Immediate referral of these patients is necessary. ${ }^{4}$

\section{Application in practice: is it an allergy or an infection?}

Table II provides practical examples of patient presentations that require treatment for a red eye. Based on the presenting symptoms and an assessment of which aetiology should be excluded, it is possible to differentiate between an allergy or infection. ${ }^{7}$

\section{Conclusion}

A red eye is a common complaint in general practice, with conjunctivitis being the most common diagnosis. Although conjunctivitis is usually a benign and self-limiting condition, it is important to make the differentiation between an allergic or infectious cause in order to treat appropriately. A relevant history should be obtained and a thorough examination conducted to assist in the diagnosis. In addition, this assessment is necessary to identify any warning signs of serious causes that warrant referral in order to expedite treatment and prevent significant morbidity.

\section{References}

1. Graham RH. Red eye. Medscape Reference. Available from www.emedicine. medscape.com/article/1192122-overview Accessed 15 January 2015

2. Cronau H, Kankanala R, Mauger T. Diagnosis and Management of Red Eye in Primary Care. American Family Physician. 2010; 81:2

3. Jacobs DS. Evaluation of the red eye. www.uptodate.com Topic 6900 , version 19.0. Accessed 15 January 2015

4. Mohamed N, Smit DP. Basic ophthalmology for the health practitioner: the red eye. South African Pharmaceutical Journal. 2013; 80(7):20-26

5. Du Toit N, Van Zyl L. The red eye. South African Family Practice. 2013;55:1

6. South African Medicines Formulary. $11^{\text {th }}$ Edition

7. Smit D. A challenging red eye clinical quiz. South African Family Practice. 2014. Vol 56 No. 2

8. Hamrah P. Dana R. Allergic conjunctivitis: Management. www.uptodate.com Topic 90512 Version 10.0 Accessed 24 February 2017 